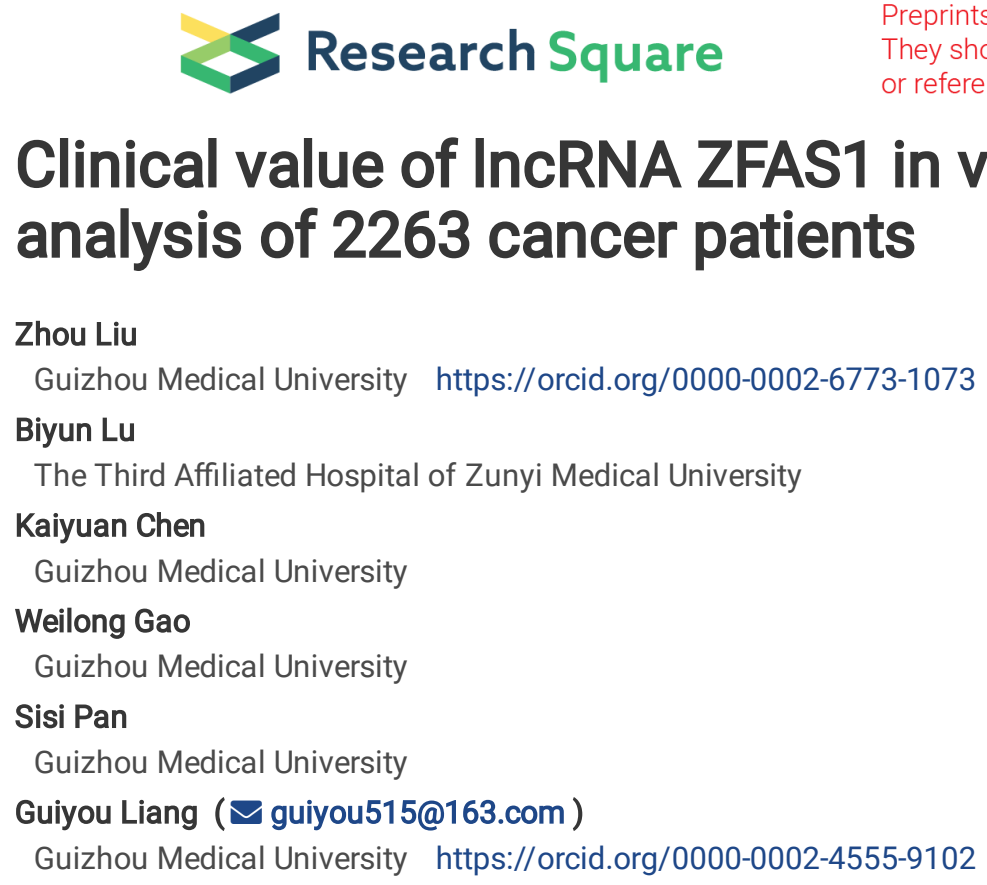

Zhou Liu

Guizhou Medical University https://orcid.org/0000-0002-6773-1073

Biyun Lu

The Third Affiliated Hospital of Zunyi Medical University

Kaiyuan Chen

Guizhou Medical University

Weilong Gao

Guizhou Medical University

Sisi Pan

Guizhou Medical University

Guiyou Liang ( $\nabla$ guiyou515@163.com )

Guizhou Medical University https://orcid.org/0000-0002-4555-9102

\title{
Clinical value of IncRNA ZFAS1 in various cancers: an updated meta- analysis of 2263 cancer patients
}

\section{Research article}

Keywords: cancer, long non-coding RNA, ZFAS1, prognosis

Posted Date: December 23rd, 2020

DOI: https://doi.org/10.21203/rs.3.rs-132447/v1

License: @ (1) This work is licensed under a Creative Commons Attribution 4.0 International License. Read Full License 


\section{Abstract}

Background: LncRNA ZNFX1 antisense RNA 1 (ZFAS1) is largely reported to be abnormally expressed in various human cancers and associated with unfavorable prognosis. So this study aims to further investigate its clinical value in multifarious cancers.

Methods: Databases of PubMed, Web of science, Cochrane library, Embase, Chinese National Knowledge Infrastructure and Wanfang was retrieved to collect eligible studies until October 22, 2020. The clinical role of ZFAS1 was comprehensively assessed by STATA 12.0. Additionally, the CeRNA network in which ZFAS1 involved was constructed. And function analysis of targeted mRNAs was performed by R package "cluster profiler".

Results: 23 studies of 2263 cancer patients met the inclusion criteria in this meta-analysis. The comprehensive results suggested that patients with elevated ZFAS1 expression got poor overall survival (OS) (HR=1.80,95\%Cl: 1.50-2.10, $P \leq 0.001)$, and they are prone to lymph node metastasis ( $\mathrm{OR}=2.67,95 \% \mathrm{Cl}: 1.73-4.14, P \leq 0.001)$, distant metastasis (DM) ( $\mathrm{OR}=3.45,95 \% \mathrm{Cl}$ : 1.61-7.39, $P=0.001)$, advanced TNM stage (HTS) (OR=2.99, 95\% Cl: 1.97-4.54, $P \leq 0.001)$, larger tumor size (LTS) (OR=1.54, 95\%Cl: 1.05-2.24, $P \leq 0.001)$, poor histologic grade (PHG) (OR=1.57, 95\%Cl: 1.09-2.26, $P=0.015)$. The CeRNA network and function analysis revealed the potential mechanism which ZFAS1 may involve in cancers.

Conclusion: The current analysis revealed that elevated ZFAS1 expression is common in various cancer and was significantly associated with poor OS and clinical characteristics, thus it may function as prognostic biomarker in various cancer. Nevertheless, larger well-designed clinical research a is still warranted to verify our findings.

\section{Background}

Cancer, as one of the leading causes of death, with high morbidity, has continually imposed heavy economical burdens on society and families. According to the latest report, 1,806,590 new cancer cases and 606,520 cancer-related deaths will occur in the United States in 2020 [1]. This severe situation has made numerous researchers to concentrate on the study of early diagnosis and efficient treatment of cancer patients. Indeed, the death rate has gradually decline with great advancement made in diagnosis and therapy of cancer, but the 5-year survival rate of cancer patients is still disappointing [2]. Thus, it's of great need to seek useful therapeutic and prognostic biomarker for the improvement of cancer patients' prognosis.

Long non-coding RNA (IncRNA), with length of more than 200 nucleotides, is a classic kind of non-coding RNA which lacks of protein coding ability. Existing evidence have proved that IncRNA can act as a significant gene regulator and participate in various biological process, including epigenetic regulation, cell cycle, alternative splicing, chromatin modification and so on [3-5]. Importantly, it's also confirmed that IncRNA can function as oncogene or tumor-suppressing gene through control of tumorigenesis, invasion, progression and metastasis in multiple cancers [6-8].

LncRNA ZNFX1 antisense RNA 1 (ZFAS1, also known as Zinc finger antisense 1), which transcribed from the antisense orientation of zinc finger NFX1-type containing 1(ZNFX1), is located on chromosome 20q13.13 [9]. Growing studies have reported abnormal expression of ZFAS1 in diverse cancers, including pancreatic cancer [10], hepatocellular carcinoma [11], melanoma [12], esophageal squamous cell carcinoma [13] and so on. Moreover, elevated ZFAS1 expression is reported to be related to poor prognosis and clinical characteristics in various cancers [14-16], which indicate that ZFAS1 may serve as a promising biomarker for the prognosis and therapy of cancer patients. However, limited by insufficient sample size in single study and inconsistent findings among studies, the clinical role of ZFAS1 in cancer deserve further study to confirm. So we performed this updated meta-analysis to comprehensively evaluate the association between ZFAS1 expression and OS and clinicopathological characteristics of cancer patients.

\section{Methods}

\section{Study selection}

The reporting of this meta-analysis complied with the Systematic Reviews and Meta-Analyses (PRISMA) guidelines [17]. Selection of eligible studies was performed in databases of PubMed, Web of Science, Chinese National Knowledge Infrastructure and Wanfang up to October 2020. The search terms were: ("IncRNA ZFAS1" or "IncRNA ZNFX1 antisense RNA 1") AND ("cancer" or "carcinoma" or "tumor" or "malignancy").

\section{Inclusion and exclusion criteria}


Inclusion criteria were as follows: (a) the ZFAS1 expression of human tumor tissues were detected via method of qRT-PCR; (b) cancer patients were divided into high expression group and low expression group according to median or average expression level of ZFAS1; (c) study provided survival information and clinicopathological parameters of cancer patients according to different ZFAS1 expression.

Studies will be excluded if they meet one or more criteria as following: (a) reviews, case reports, letters, meta-analysis, conference articles and laboratory study; (b) study without survival information or clinicopathological features of patients; (c) high or low ZFAS1 expression were not defined.

\section{Data extraction and quality assessment}

In strict accordance with inclusion and exclusion criteria, qualified original literature data assessment and related data extraction were independently completed by two investigators (Zhou Liu and Biyun Lu), and any disagreement encountered is resolved through consultation with third investigator (Kaiyuan Chen). The following information was extracted from each literature: first author, publication year, country, tumor type, detection method, total number of cases, survival information and clinicopathological parameters. If there were both univariate and multivariate analysis in the include study, the results of multivariate analysis will be applied. If only the survival curve is provided in the study, then Engauge Digitizer v10.4 software will be employed to extract HR and 95\% Cl. Quality assessment was conducted through Newcastle-Ottawa-Scale (NOS) criteria. High-quality studies were defined as the NOS score $\geq 6$.

\section{CeRNA network construction}

By using starbase v2.0 (http://starbase.sysu.edu.cn/), the targeted miRNA of ZFAS1 was predicted. And the targeted mRNA mining of predicted miRNA was performed via miRWalk with the filter set as 0.95, 3UTR, TargetScan, miRDB, miRTarBase. Then the targeted mRNAs were applied to perform Gene Ontology (GO) and Kyoto Encyclopedia of Genes and Genomes (KEGG) pathway analysis by R package "cluster profiler".

\section{Statistical analysis}

Stata 12.0 software (StataCorp, College Station, Texas USA) was used to analyze the extracted data. Pooled hazards ratios (HRs) or odds ratios (ORs) with 95\% confidence interval (CI) were used to assess the correlation of prognosis and clinicopathological features with ZFAS1 expression, respectively. Heterogeneity test was performed by Cochran's Q test and $\mathrm{I}^{2}$ statistic. Random-effect model was used if the heterogeneity was significant $\left(I^{2} \geq 50 \%\right.$, and $\left.P<0.05\right)$, instead, fixed-effect model will be chosen. The robustness and heterogeneity source of results was tested via sensitivity analysis and subgroup analysis, respectively. Potential publication bias was assessed by and Begg's test $\mathbb{Z}$ and $\operatorname{Pr}>|z| \varangle 0.05$ indicates no publication bias existed. Statistically significance was defined if $P<0.05$.

\section{Results}

\section{Details of included study}

As shown in Figure 1, after strict selection by two authors, 23 studies of 2263 cancer patients were included in this study. The detailed characteristics of the 23 studies were summarized in Table1. Those studies were published from 2015 to 2020 , with average sample size about 103. The included 2263 patients all come from China. 16 types of tumors were included in this study, which contains pancreatic adenocarcinoma (PAAD) [10], hepatocellular carcinoma (HCC) [11, 18], melanoma [12], esophageal squamous cell carcinoma (ESCC) [13, 19], hepatoblastoma (HB) [20], cholangiocarcinoma (CCA) [14], papillary thyroid carcinoma (PTC) [21], prostate cancer (PCa) [22], clear cell renal cell carcinoma (ccRCC) [15], colorectal cancer (CRC) [16, 23, 24], bladder cancer [25, 26], nasopharyngeal carcinoma (NPC) [27], gastric cancer (GC) [28], epithelial ovarian cancer (EOC) [29], non-small cell lung cancer (NSCLC) [30], glioma [31]. ZFAS1 expression in tumor tissues were all detected by qRT-PCR. The NOS score of included studies are all $\geq 6 \varangle$ which means they are all high quality studies. Additionally, the study of Shi et al. provided two independent cohorts of patients, so we didn't merge the data together, but named the data from primary cohort as Shi HT and the validation cohort as Shi HT-1.

\section{ZFAS1 expression and OS}

In this part, 16 studies of 1637 patients were included. Among them, 5 studies directly provided $\mathrm{HR}$ and $95 \% \mathrm{Cl}$, and the survival data from the other 11 studies were indirectly extracted from survive curve. The results revealed that patients with high ZFAS1 expression underwent poor OS (OR=1.80, 95\% Cl: 1.50-2.10, P $\leq 0.001$, Figure 2). It's found that many different characteristics were existed among the study of OS, therefore, to exclude potential bias, subgroup analysis on the basis of HR methods, sample size, follow-up month and tumor type indicate that high ZFAS1 expression was correlated to poor OS in the above 8 subgroups (Figure 3), which indicates there exists no potential bias in study about OS. Additionally, sensitivity analysis and Begg's test further confirms the robustness of this results (Figure 4). 


\section{ZFAS1 expression and clinical characteristics}

OR and $95 \% \mathrm{Cl}$ was applied to evaluate the relationship between ZFAS1 expression and various clinical characteristics. As manifested in Figure 5, the results demonstrated that high ZFAS1 expression was related to high tumor stage (HTS) (OR=2.99, 95\%Cl: 1.97-4.54, $\mathrm{P} \leq 0.001$, Figure 5a), larger tumor size (LTS) (OR=1.54, 95\%Cl: 1.05-2.24, $\mathrm{P} \leq 0.001$, Figure $5 \mathrm{~b})$, lymph node metastasis (LNM) (OR=2.67, 95\%Cl: 1.734.14, $P \leq 0.001$, Figure 5c), poor histologic grade $(P H G)(O R=1.57,95 \% \mathrm{Cl}: 1.09-2.26, P=0.015$, Figure $5 d)$, distant metastasis (DM) $(O R=3.45$, $95 \% \mathrm{Cl}: 1.61-7.39, \mathrm{P}=0.001$, Figure $\mathrm{S} 1 \mathrm{a})$, but not to age (OR=1.06, 95\% Cl: $0.89-1.26, P=0.499$, Figure $\mathrm{S} 1 \mathrm{~b})$ and gender $(\mathrm{OR}=1.13,95 \% \mathrm{Cl}: 0.94$ $1.36, \mathrm{P}=0.209$, Figure $\mathrm{S} 1 \mathrm{c})$.

And Begg's test in Figure 6 manifested that there exists no publication bias in the studies of $L N M(\operatorname{Pr}>|z|=0.322), D M(\operatorname{Pr}>|z|=0.060), H T S$ $(\operatorname{Pr}>|z|=0.173), \operatorname{LTS}(\operatorname{Pr}>|z|=1.000)$, PHG $(\operatorname{Pr}>|z|=0.381)$.

\section{CeRNA network}

Growing studies have found out that CeRNA network plays a significant role in the regulation of IncRNA to cancer. To explore the potential mechanism of ZFAS1 in cancer development, the CeRNA network centered on ZFAS1 was constructed. As shown in Figure 6, this CeRNA network which contains 95 nodes and 103 edges manifested lots of ZFAS1/miRNA/mRNA axis that may participate in the regulation of occurrence and development of cancer. GO and KEGG analysis indicated the biological functions and pathway the targeted mRNAs may involve in. Those results above together provide meaningful clues for future mechanism research of ZFAS1 in cancer.

\section{Discussion}

Cancer has always been a great concern to human health. Due to its indetectable onset, when diagnosed, most cancer patients tend to have advanced clinical stage, LNM and DM, and current cancer therapy can't effectively stop its development, which make them unfortunately miss the optimal treatment time and have poor prognosis. Therefore, the identification of prospective biomarker for the diagnosis, treatment and prognosis of cancer is urgent.

Recently, plenty of studies indicated that several IncRNAs may serve as a promising prognostic biomarker for cancer patients, such as SNHG1 [32], linc00152 [33], PCAT-1 [34], FAM83H-AS1 [35] and so on. And ZFAS1 is exactly one of them. In this meta-analysis, our results showed that increased ZFAS1 expression can predict poor prognosis in diverse cancer patients ( $\mathrm{OR}=1.80,95 \% \mathrm{Cl}: 1.50-2.10, \mathrm{P} \leq 0.001)$. Furthermore, subgroup analysis, sensitivity analysis and Begg's test performed in this study showed that no potential heterogeneity exists among included studies, which further testified the stability of our results. Meanwhile, elevated ZFAS1 expression was also associated with clinical characteristics, including HTS (OR=2.99, 95\%Cl: 1.97-4.54, $\mathrm{P} \leq 0.001)$, larger tumor size (OR=1.54, 95\%Cl: 1.05-2.24, $\mathrm{P} \leq 0.001)$, LNM $(\mathrm{OR}=2.67,95 \% \mathrm{Cl}: 1.73-4.14, \mathrm{P} \leq 0.001)$, PHG (OR=1.57, 95\%Cl: 1.09-2.26, $\mathrm{P}=0.015), \mathrm{DM}(\mathrm{OR}=3.45,95 \% \mathrm{Cl}: 1.61-7.39, \mathrm{P}=0.001)$. Taken together, our results demonstrated that upregulated ZFAS1 expression can be regarded as specific indicator of poor prognosis in cancer patients.

Since ZFAS1 was firstly discovered by Askarian-Amiri in breast cancer [9], mounting evidence have demonstrated that the dysregulation of ZFAS1 expression plays a critical role in the proliferation, invasion and metastasis of various cancers. And the carcinogenic molecular mechanism of ZFAS1 has been partly clarified that it usually functions as CeRNA of miRNA to regulate downstream mRNA expression to affect manifold biological behaviors of tumor cell. Duan et al. found that ZFAS1 was obviously overexpressed in HCC and connected with worse prognosis of HCC patients, and silencing of ZFAS1 can suppress cell proliferation, invasion, migration and epithelial-mesenchymal transition (EMT) through regulation of the miR-624/MDK/ERK/JNK/AKT signaling pathway [11]. Several researchers have demonstrated that ZFAS1 was upregulated in CRC and can serve as a prognostic factor for CRC patients. Among them, Chen et al. revealed that ZFAS1 can promote tumor growth, metastasis, and angiogenesis in CRC thorough sponging of miR-150-5p [16]; Xie et al. found that ZFAS1 promotes cell proliferation and invasion in CRC via sponging to miR-484 [23]; and Fang et al. demonstrated that ZFAS1 facilitates the progression of CRC by regulation of ZEB1 expression [36]. Meanwhile, ZFAS1 can exert oncogenic effect in PAAD through miR-3924/ROCK2 pathway [10], and knockdown of ZFAS1 can reduce tumor progression in ovarian cancer via sponging of miR-150-5p to modulate RAB9A expression [29]. Xiao et al. noted that ZFAS1 acts as CeRNA of miR-193a-3p to control HB growth by targeting RALY via HGF/c-Met Pathway. Moreover, the CeRNA network build in our study may lead to another novel direction on the path of cancer mechanism research about ZFAS1.

Notably, several researchers have explored the role of ZFAS1 in cancers before our meta-analysis, but obvious difference can be observed in our study. Firstly, a total of 23 studies of 2263 cancer patients were included in our study, the most sample size in studies of Dong et al. [37] is only 12 studies of 1075 patients, therefore, larger sample size in our study make our findings more convincible. Secondly, the prognostic role of ZFAS1 in more cancer types including PAAD, ESCC, HB, CCA, PTC, PCa, CCRCC, NPC and bladder cancer were explored in current study, which make our results more applicable. Thirdly, we firstly revealed that high ZFAS1 expression is significantly with DM. Lastly, we firstly constructed a CeRNA network in which ZFAS1 participated, which contribute to the discovery of new regulation mechanism. 
However, it's undeniable that some limitations can be found in our study. Firstly, patients included in our study are all Chinese, which may restrict the applicability of our findings in other race. Secondly, some HRs were extracted from survive curve, which may affect the reliability of our results. Lastly, the cut-off value defines high and low expression of ZFAS1 were not consistent among studies, which may cause potential heterogeneity. Consequently, more studies of high-quality and diverse ethnicity are required to further verify our findings.

\section{Conclusions}

In short, our findings indicated that high ZFAS1 expression is significantly associated with poor OS and clinicopathological features including advanced tumor stage, lymph node metastasis, larger tumor size, poor differentiation and distant metastasis in cancer patients, thus it may be qualified as a prognostic biomarker for cancer patients.

\section{Abbreviations}

ZFAS1: ZNFX1 antisense RNA 1; OS: overall survival; IncRNA: Long non-coding RNA; ZNFX1: zinc finger NFX1-type containing 1; NOS: Newcastle-Ottawa-Scale; GO: Gene Ontology; KEGG: Kyoto Encyclopedia of Genes and Genomes; HR: hazards ratios; OR: odds ratios; Cl: confidence interval; PAAD: pancreatic adenocarcinoma; HCC: hepatocellular carcinoma; ESCC: esophageal squamous cell carcinoma; HB: hepatoblastoma; CCA: cholangiocarcinoma; PTC: papillary thyroid carcinoma; PCa: prostate cancer; ccRCC: clear cell renal cell carcinoma; CRC: colorectal cancer; NPC: nasopharyngeal carcinoma; GC: gastric cancer; EOC: epithelial ovarian cancer; NSCLC: non-small cell lung cancer; HTS: high tumor stage; LTS: larger tumor size; LNM: lymph node metastasis; PHG: poor histologic grade; DM: distant metastasis.

\section{Declarations}

\section{Ethics approval and consent to participate}

Not applicable.

\section{Consent for publication}

All the listed authors agree to publish.

Availability of data and materials

All data are included in this article.

\section{Competing interests}

The authors declare no underlying conflicts of interest.

\section{Funding}

This meta-analysis was supported by the National Natural Science Foundation of China (N0.81960051; Recipient: Guiyou Liang). The National Natural Science Foundation of China was not involved in the design of the study; collection, analysis, and interpretation of data; and in writing the manuscript.

\section{Authors' contributions}

Conception: ZL, GL. Data analysis: BL, KC. Manuscript draft: ZL, BL, WG. Manuscript revision: GL, SP. All authors read and approved the final manuscript.

\section{Acknowledgements}

Not applicable.

\section{References}

1. Siegel RL, Miller KD and Jemal A. Cancer statistics, 2020. CA: a cancer journal for clinicians. 2020;70(1):7-30

2. Siegel RL, Miller KD and Jemal A. Cancer statistics, 2019. CA: a cancer journal for clinicians. 2019;69(1):7-34

3. Zhu J, Kong F, Xing L, Jin Z and Li Z. Prognostic and clinicopathological value of long noncoding RNA XIST in cancer. Clinica chimica acta; international journal of clinical chemistry. 2018;479:43-47 
4. Taft RJ, Pang KC, Mercer TR, Dinger M and Mattick JS. Non-coding RNAs: regulators of disease. The Journal of pathology. 2010;220(2):126-139

5. Beermann J, Piccoli MT, Viereck J and Thum T. Non-coding RNAs in Development and Disease: Background, Mechanisms, and Therapeutic Approaches. Physiological reviews. 2016;96(4):1297-1325

6. Sharma GG, Okada Y, Von Hoff D and Goel A. Non-coding RNA biomarkers in pancreatic ductal adenocarcinoma. Seminars in cancer biology. 2020:

7. Sur S, Nakanishi H, Steele R, Zhang D, Varvares MA and Ray RB. Long non-coding RNA ELDR enhances oral cancer growth by promoting ILF3-cyclin E1 signaling. EMBO reports. 2020:e51042

8. Mu M, Niu W, Zhang X, Hu S and Niu C. LncRNA BCYRN1 inhibits glioma tumorigenesis by competitively binding with miR-619-5p to regulate CUEDC2 expression and the PTEN/AKT/p21 pathway. Oncogene. 2020:

9. Askarian-Amiri ME, Crawford J, French JD, Smart CE, Smith MA, Clark MB, Ru K, Mercer TR, Thompson ER, Lakhani SR et al. SNORD-host RNA Zfas1 is a regulator of mammary development and a potential marker for breast cancer. RNA (New York, NY). 2011;17(5):878-891

10. Liu J, Zhu Y and Ge C. LncRNA ZFAS1 promotes pancreatic adenocarcinoma metastasis via the RHOA/ROCK2 pathway by sponging miR-3924. Cancer cell international. 2020;20:249

11. Duan R, Li C, Wang F, Han F and Zhu L. The Long Noncoding RNA ZFAS1 Potentiates the Development of Hepatocellular Carcinoma via the microRNA-624/MDK/ERK/JNK/P38 Signaling Pathway. OncoTargets and therapy. 2020;13:4431-4444

12. Liang L, Zhang Z, Qin X, Gao Y, Zhao P, Liu J and Zeng W. Long noncoding RNA ZFAS1 promotes tumorigenesis through regulation of miR-150-5p/RAB9A in melanoma. Melanoma research. 2019;29(6):569-581

13. Li Z, Qin X, Bian W, Li Y, Shan B, Yao Z and Li S. Exosomal IncRNA ZFAS1 regulates esophageal squamous cell carcinoma cell proliferation, invasion, migration and apoptosis via microRNA-124/STAT3 axis. Journal of experimental \& clinical cancer research : CR. 2019;38(1):477

14. Li Z, Jiang X, Huang L, Li J, Ji D, Xu Y, Leng K and Cui Y. Up-regulation of ZFAS1 indicates dismal prognosis for cholangiocarcinoma and promotes proliferation and metastasis by modulating USF1 via miR-296-5p. Journal of cellular and molecular medicine. 2019;23(12):8258-8268

15. Dong D, Mu Z, Wei N, Sun M, Wang W, Xin N, Shao Y and Zhao C. Long non-coding RNA ZFAS1 promotes proliferation and metastasis of clear cell renal cell carcinoma via targeting miR-10a/SKA1 pathway. Biomedicine \& pharmacotherapy $=$ Biomedecine \& pharmacotherapie. 2019;111:917-925

16. Chen X, Zeng K, Xu M, Hu X, Liu X, Xu T, He B, Pan Y, Sun H and Wang S. SP1-induced IncRNA-ZFAS1 contributes to colorectal cancer progression via the miR-150-5p/VEGFA axis. Cell death \& disease. 2018;9(10):982

17. Moher D, Liberati A, Tetzlaff J and Altman DG. Preferred reporting items for systematic reviews and meta-analyses: the PRISMA statement. Journal of clinical epidemiology. 2009;62(10):1006-1012

18. Li T, Xie J, Shen C, Cheng D, Shi Y, Wu Z, Deng X, Chen H, Shen B, Peng C et al. Amplification of Long Noncoding RNA ZFAS1 Promotes Metastasis in Hepatocellular Carcinoma. Cancer research. 2015;75(15):3181-3191

19. Shi H, Liu Z, Pei D, Jiang Y, Zhu H and Chen B. Development and validation of nomogram based on IncRNA ZFAS1 for predicting survival in lymph node-negative esophageal squamous cell carcinoma patients. Oncotarget. 2017;8(35):59048-59057

20. Cui X, Wang Z, Liu L, Liu X, Zhang D, Li J, Zhu J, Pan J, Zhang D and Cui G. The Long Non-coding RNA ZFAS1 Sponges miR-193a-3p to Modulate Hepatoblastoma Growth by Targeting RALY via HGF/c-Met Pathway. Frontiers in cell and developmental biology. 2019;7:271

21. Tong H, Zhuang X, Cai J, Ding Y, Si Y, Zhang H and Shen M. Long noncoding RNA ZFAS1 promotes progression of papillary thyroid carcinoma by sponging miR-590-3p and upregulating HMGA2 expression. OncoTargets and therapy. 2019;12:7501-7512

22. Cui X, Piao C, Lv C, Lin X, Zhang Z and Liu X. ZNFX1 anti-sense RNA 1 promotes the tumorigenesis of prostate cancer by regulating cMyc expression via a regulatory network of competing endogenous RNAs. Cellular and molecular life sciences : CMLS. 2020;77(6):11351152

23. Xie S, Ge Q, Wang X, Sun X and Kang Y. Long non-coding RNA ZFAS1 sponges miR-484 to promote cell proliferation and invasion in colorectal cancer. Cell cycle (Georgetown, Tex). 2018;17(2):154-161

24. Wang $\mathrm{W}$ and Xing C. Upregulation of long noncoding RNA ZFAS1 predicts poor prognosis and prompts invasion and metastasis in colorectal cancer. Pathology, research and practice. 2016;212(8):690-695

25. Yang H, Li G, Cheng B and Jiang R. ZFAS1 functions as an oncogenic long non-coding RNA in bladder cancer. Bioscience reports. 2018;38(3):

26. Wang JS, Liu QH, Cheng XH, Zhang WY and Jin YC. The long noncoding RNA ZFAS1 facilitates bladder cancer tumorigenesis by sponging miR-329. Biomedicine \& pharmacotherapy = Biomedecine \& pharmacotherapie. 2018;103:174-181

Page 6/15 
27. Chen X, Li J, Li CL and Lu X. Long non-coding RNA ZFAS1 promotes nasopharyngeal carcinoma through activation of Wnt/ $\beta$-catenin pathway. European review for medical and pharmacological sciences. 2018;22(11):3423-3429

28. Nie F, Yu X, Huang M, Wang Y, Xie M, Ma H, Wang Z, De W and Sun M. Long noncoding RNA ZFAS1 promotes gastric cancer cells proliferation by epigenetically repressing KLF2 and NKD2 expression. Oncotarget. 2017;8(24):38227-38238

29. Xia B, Hou Y, Chen H, Yang S, Liu T, Lin M and Lou G. Long non-coding RNA ZFAS1 interacts with miR-150-5p to regulate Sp1 expression and ovarian cancer cell malignancy. Oncotarget. 2017;8(12):19534-19546

30. Tian FM, Meng FQ and Wang XB. Overexpression of long-noncoding RNA ZFAS1 decreases survival in human NSCLC patients. European review for medical and pharmacological sciences. 2016;20(24):5126-5131

31. Lv QL, Chen SH, Zhang X, Sun B, Hu L, Qu Q, Huang YT, Wang GH, Liu YL, Zhang YY et al. Upregulation of long noncoding RNA zinc finger antisense 1 enhances epithelial-mesenchymal transition in vitro and predicts poor prognosis in glioma. Tumour biology : the journal of the International Society for Oncodevelopmental Biology and Medicine. 2017;39(3):1010428317695022

32. Dong B, Chen X, Zhang Y, Zhu C and Dong Q. The prognostic value of IncRNA SNHG1 in cancer patients: a meta-analysis. BMC cancer. 2019;19(1):780

33. Wang H, Liu Y and Tang A. Prognostic Values of Long Noncoding RNA linc00152 in Various Carcinomas: An Updated Systematic Review and Meta-Analysis. The oncologist. 2020;25(1):e31-e38

34. Liang C, Qi Z, Ge H, Liang C, Zhang Y, Wang Z, Li R and Guo J. Long non-coding RNA PCAT-1 in human cancers: A meta-analysis. Clinica chimica acta; international journal of clinical chemistry. 2018;480:47-55

35. Yang Q, Wang J, Zhong P, Mou T, Hua H, Liu P and Xie F. The clinical prognostic value of IncRNA FAM83H-AS1 in cancer patients: a meta-analysis. Cancer cell international. 2020;20:72

36. Fang C, Zan J, Yue B, Liu C, He C and Yan D. Long non-coding ribonucleic acid zinc finger antisense 1 promotes the progression of colonic cancer by modulating ZEB1 expression. Journal of gastroenterology and hepatology. 2017;32(6):1204-1211

37. Dong D, Mu Z, Wang W, Xin N, Song X, Shao Y and Zhao C. Prognostic value of long noncoding RNA ZFAS1 in various carcinomas: a meta-analysis. Oncotarget. 2017;8(48):84497-84505

\section{Tables}

Table 1 Main characteristics of included studies. Note: indirectly, HR extracted from survival curve; directly, HR extracted from paper; -, not available; OS, overall survival. 


\begin{tabular}{|c|c|c|c|c|c|c|c|c|c|c|c|}
\hline \multirow[b]{2}{*}{ study } & \multirow[b]{2}{*}{ year } & \multirow[b]{2}{*}{ country } & \multirow[b]{2}{*}{ tumor type } & \multirow[t]{2}{*}{$\begin{array}{l}\text { sample } \\
\text { size(n) }\end{array}$} & \multicolumn{2}{|c|}{$\begin{array}{l}\text { ZFAS1 } \\
\text { expression }\end{array}$} & \multirow[t]{2}{*}{$\begin{array}{l}\text { outcome } \\
\text { information }\end{array}$} & \multirow{2}{*}{$\begin{array}{l}\text { Hazard } \\
\text { Ratios } \\
\text { methods }\end{array}$} & \multirow{2}{*}{$\begin{array}{l}\text { follow- } \\
\text { up } \\
\text { months }\end{array}$} & \multirow[t]{2}{*}{$\begin{array}{l}\text { Laboratory } \\
\text { method }\end{array}$} & \multirow[t]{2}{*}{$\begin{array}{l}\text { NOS } \\
\text { score }\end{array}$} \\
\hline & & & & & high & low & & & & & \\
\hline $\begin{array}{l}\text { Liu } \\
\text { JY }\end{array}$ & 2020 & China & $\begin{array}{l}\text { pancreatic } \\
\text { adenocarcinoma }\end{array}$ & 83 & 20 & 63 & OS & indirectly & $>60$ & qRT-PCR & 7 \\
\hline $\begin{array}{l}\text { Duan } \\
\text { R }\end{array}$ & 2020 & China & $\begin{array}{l}\text { hepatocellular } \\
\text { carcinoma }\end{array}$ & 94 & 47 & 47 & os & indirectly & $\leq 60$ & qRT-PCR & 8 \\
\hline $\begin{array}{l}\text { Liang } \\
\text { LL }\end{array}$ & 2019 & China & melanoma & 45 & 23 & 22 & OS & indirectly & $\leq 60$ & qRT-PCR & 6 \\
\hline Li ZR & 2019 & China & $\begin{array}{l}\text { esophageal } \\
\text { squamous cell } \\
\text { carcinoma }\end{array}$ & 136 & 69 & 67 & - & - & - & qRT-PCR & 7 \\
\hline $\begin{array}{l}\text { Cui } \\
\text { XC }\end{array}$ & 2019 & China & hepatoblastoma & 70 & 42 & 28 & - & - & - & qRT-PCR & 8 \\
\hline Li ZL & 2019 & China & cholangiocarcinoma & 64 & 30 & 34 & OS & indirectly & $\leq 60$ & qRT-PCR & 7 \\
\hline $\begin{array}{l}\text { Tong } \\
\mathrm{HC}\end{array}$ & 2019 & China & $\begin{array}{l}\text { papillary thyroid } \\
\text { carcinoma }\end{array}$ & 80 & 48 & 32 & - & - & - & qRT-PCR & 8 \\
\hline $\begin{array}{l}\text { Cui } \\
\text { XL }\end{array}$ & 2019 & China & prostate cancer & 52 & 26 & 26 & - & - & - & qRT-PCR & 8 \\
\hline $\begin{array}{l}\text { Dong } \\
\text { D }\end{array}$ & 2019 & China & $\begin{array}{l}\text { clear cell renal cell } \\
\text { carcinoma }\end{array}$ & 60 & 30 & 30 & os & indirectly & $\leq 60$ & qRT-PCR & 6 \\
\hline $\begin{array}{l}\text { Chen } \\
\text { XX }\end{array}$ & 2018 & China & colorectal cancer & 112 & 56 & 56 & os & directly & $>60$ & qRT-PCR & 8 \\
\hline $\begin{array}{l}\text { Chen } \\
X\end{array}$ & 2018 & China & $\begin{array}{l}\text { nasopharyngeal } \\
\text { carcinoma }\end{array}$ & 46 & 38 & 38 & OS & indirectly & $>60$ & qRT-PCR & 7 \\
\hline $\begin{array}{l}\text { Yang } \\
\text { HF }\end{array}$ & 2018 & China & bladder cancer & 102 & 51 & 51 & - & - & - & qRT-PCR & 8 \\
\hline $\begin{array}{l}\text { Xie } \\
\text { SP }\end{array}$ & 2018 & China & colorectal cancer & 49 & 25 & 24 & os & indirectly & $\leq 60$ & qRT-PCR & 6 \\
\hline $\begin{array}{l}\text { Shi } \\
\text { HT }\end{array}$ & 2017 & China & $\begin{array}{l}\text { esophageal } \\
\text { squamous cell } \\
\text { carcinoma }\end{array}$ & 246 & 123 & 123 & os & directly & $>60$ & qRT-PCR & 8 \\
\hline $\begin{array}{l}\text { Shi } \\
\text { HT-1 }\end{array}$ & 2017 & China & $\begin{array}{l}\text { esophageal } \\
\text { squamous cell } \\
\text { carcinoma }\end{array}$ & 152 & 76 & 76 & os & directly & $>60$ & qRT-PCR & 6 \\
\hline $\begin{array}{l}\mathrm{Nie} \\
\mathrm{FQ}\end{array}$ & 2017 & China & gastric cancer & 54 & 27 & 27 & OS & indirectly & $\leq 60$ & qRT-PCR & 7 \\
\hline $\begin{array}{l}\text { Fang } \\
\text { CY }\end{array}$ & 2017 & China & colonic cancer & 73 & 36 & 37 & - & - & - & qRT-PCR & 7 \\
\hline $\begin{array}{l}\text { Xia } \\
\text { BR }\end{array}$ & 2017 & China & $\begin{array}{l}\text { epithelial ovarian } \\
\text { cancer }\end{array}$ & 60 & 30 & 30 & os & indirectly & $>60$ & qRT-PCR & 7 \\
\hline Lv QL & 2017 & China & glioma & 68 & 27 & 42 & os & directly & $\leq 60$ & qRT-PCR & 6 \\
\hline $\begin{array}{l}\text { Tian } \\
\text { FM }\end{array}$ & 2016 & China & $\begin{array}{l}\text { non small cell lung } \\
\text { cancer }\end{array}$ & 173 & 85 & 88 & os & directly & $>60$ & qRT-PCR & 8 \\
\hline $\begin{array}{l}\text { Wang } \\
\text { WL }\end{array}$ & 2016 & China & colorectal cancer & 159 & 79 & 80 & os & indirectly & $>60$ & qRT-PCR & 6 \\
\hline $\mathrm{LiT}$ & 2015 & China & $\begin{array}{l}\text { hepatocellular } \\
\text { carcinoma }\end{array}$ & 113 & 57 & 56 & - & - & - & qRT-PCR & 7 \\
\hline $\begin{array}{l}\text { Wang } \\
\text { JS }\end{array}$ & 2018 & China & bladder cancer & 172 & - & - & OS & indirectly & $\leq 60$ & qRT-PCR & 7 \\
\hline
\end{tabular}

Table 2 The association between ZFAS1 expression and clinicopathological features. 


\begin{tabular}{|lllllll|}
\hline & & & & & Heterogeneity \\
\hline Clinicopathological features & studies & patients & OR $(95 \% \mathrm{Cl})$ & P-value & I-squared & P-value \\
\hline Age (elderly vs young) & 22 & 2122 & $1.06(0.89,1.26)$ & 0.499 & $0.00 \%$ & 0.604 \\
\hline Gender (male vs female) & 20 & 2010 & $1.13(0.94,1.36)$ & 0.209 & $19.50 \%$ & 0.212 \\
\hline TNM stage (III+IV vs I+ II) & 18 & 1579 & $2.99(1.97-4.54)$ & $\leq 0.001$ & $70.10 \%$ & $\leq 0.001$ \\
\hline Lymph node metastasis (present vs absent) & 15 & 1034 & $2.67(1.73-4.14)$ & $\leq 0.001$ & $65.50 \%$ & $\leq 0.001$ \\
\hline distant metastasis (present vs absent) & 6 & 419 & $3.45(1.61-7.39)$ & 0.001 & $59.00 \%$ & 0.032 \\
\hline Differentiation (poor vs well) & 14 & 1490 & $1.57(1.09-2.26)$ & 0.015 & $56.80 \%$ & 0.005 \\
\hline Tumor size (large vs small) & 16 & 1494 & $1.54(1.05-2.24)$ & 0.025 & $65.30 \%$ & $\leq 0.001$ \\
\hline
\end{tabular}

\section{Figures}
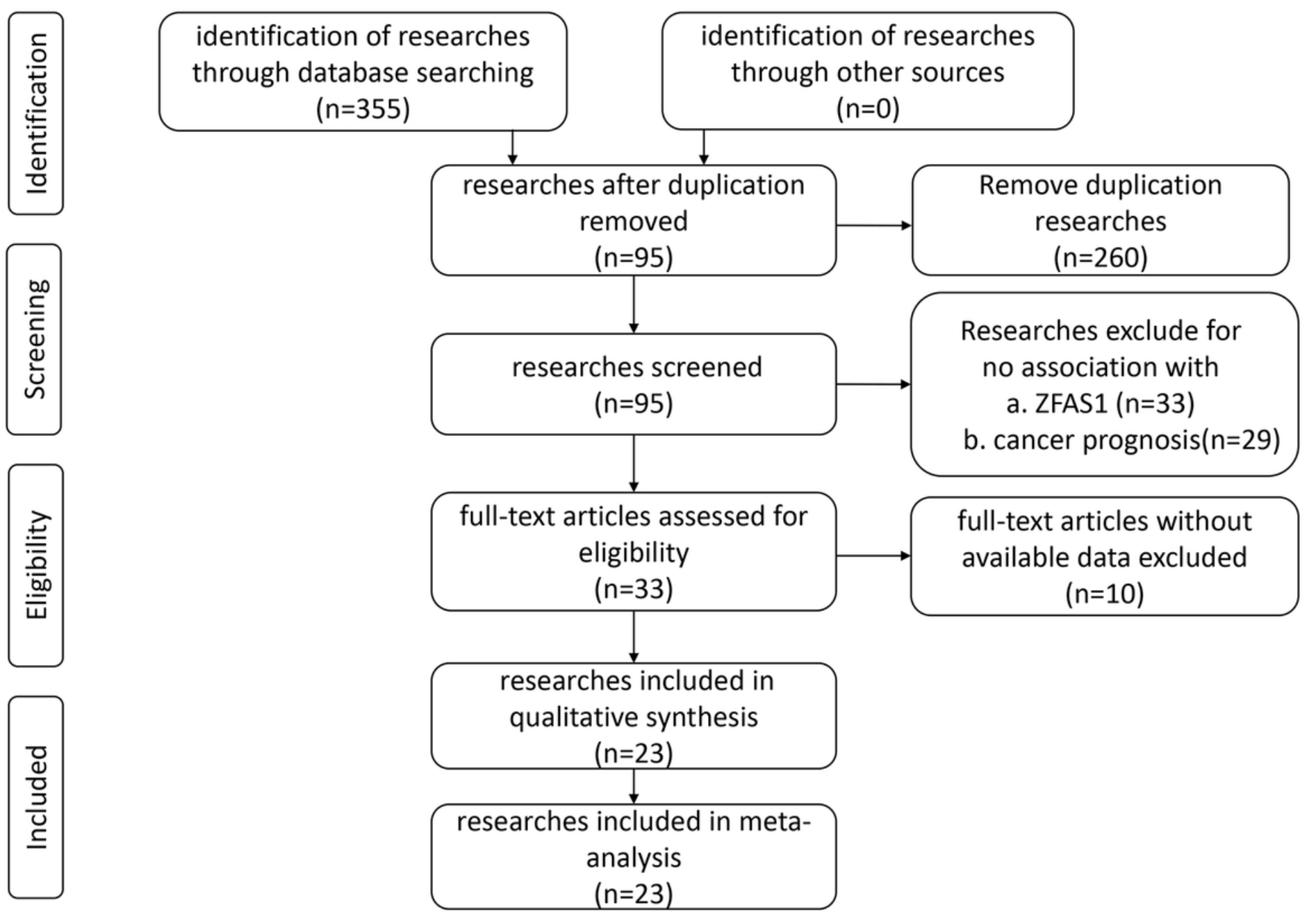

Figure 1

Flow diagram of detailed selection process of this meta-analysis 
Study

$\%$

ID

$\operatorname{HR}(95 \% \mathrm{Cl})$

Weight

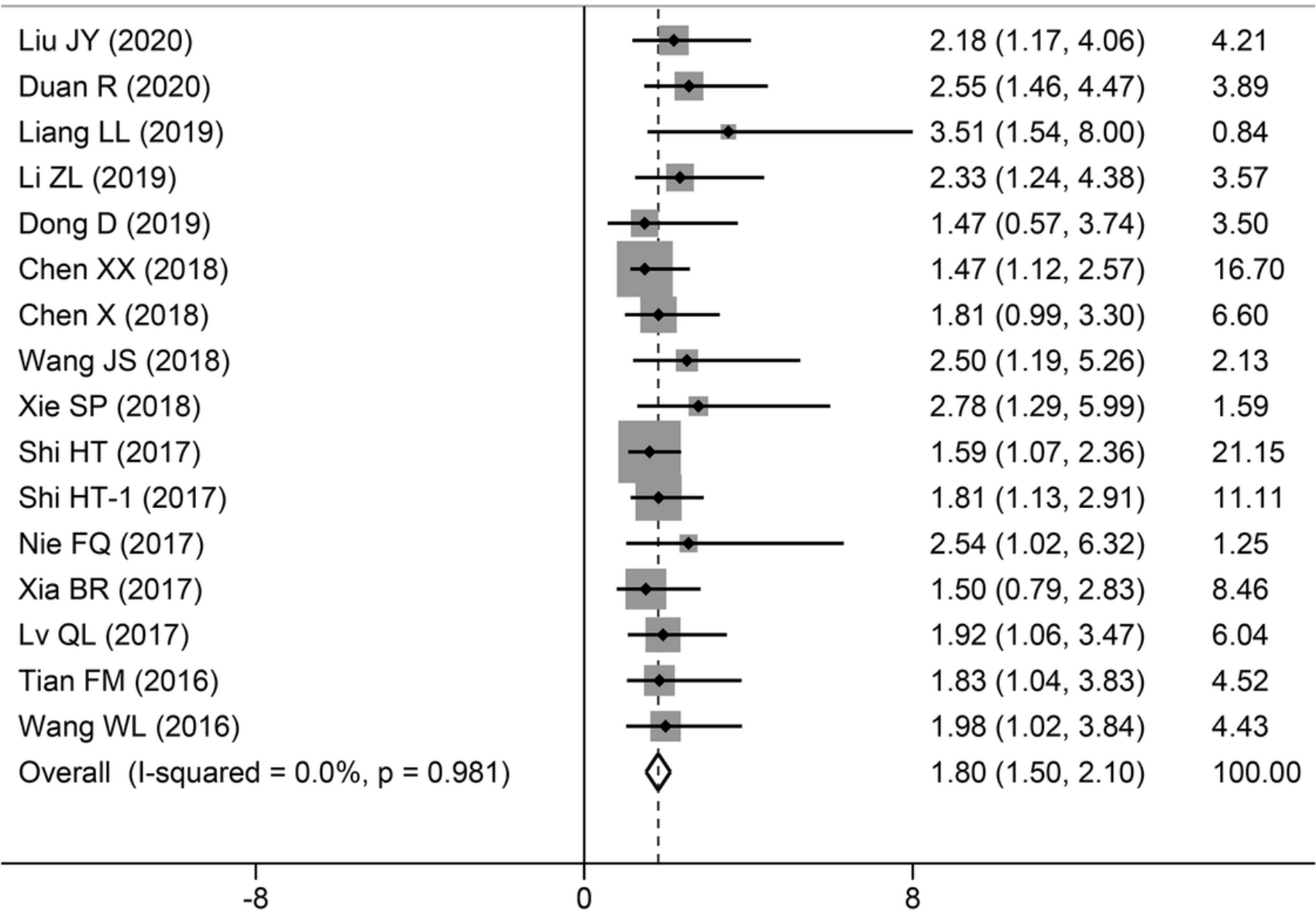

\section{Figure 2}

Forest plot of the association between ZFAS1 expression and overall survival. 
a

\begin{tabular}{|c|c|c|c|}
\hline \multicolumn{2}{|l|}{$\begin{array}{l}\text { Study } \\
\text { ID }\end{array}$} & \multirow[t]{2}{*}{$\mathrm{HR}(95 \% \mathrm{Cl})$} & \multirow[t]{2}{*}{$\begin{array}{l}\% \\
\text { Weight }\end{array}$} \\
\hline digestive cancer & & & \\
\hline Liu JY (2020) & $\rightarrow-$ & $2.18(1.17,4.06)$ & 4.37 \\
\hline Duan R (2020) & $\rightarrow$ & $2.55(1.46,4.47)$ & 4.02 \\
\hline Li ZL (2019) & + & $2.33(1.24,4.38)$ & 3.70 \\
\hline Chen XX (2018) & $\leftarrow$ & $1.47(1.12,2.57)$ & 17.29 \\
\hline Xie SP (2018) & & $2.78(1.29,5.99)$ & 1.65 \\
\hline Shi HT (2017) & $\rightarrow$ & $1.59(1.07,2.36)$ & 21.91 \\
\hline Shi HT-1 (2017) & $\rightarrow$ & $1.81(1.13,2.91)$ & 11.51 \\
\hline Nie FQ (2017) & & $2.54(1.02,6.32)$ & 1.30 \\
\hline Wang WL (2016) & $\rightarrow$ & $1.98(1.02,3.84)$ & 4.58 \\
\hline Subtotal $(I-$ squared $=0.0 \%, p=0.869)$ & 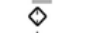 & $1.80(1.44,2.16)$ & 70.33 \\
\hline \multicolumn{4}{|l|}{ non-digestive cancer } \\
\hline Liang LL (2019) & & $3.51(1.54,8.00)$ & 0.87 \\
\hline Dong D (2019) & $\rightarrow$ & $1.47(0.57,3.74)$ & 3.63 \\
\hline Chen X (2018) & $\rightarrow-1$ & $1.39(0.50,3.84)$ & 3.27 \\
\hline Wang JS (2018) & 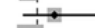 & $2.50(1.19,5.26)$ & 2.20 \\
\hline Xia BR (2017) & $\rightarrow-$ & $1.50(0.79,2.83)$ & 8.76 \\
\hline Lv QL (2017) & $\rightarrow$ & $1.92(1.06,3.47)$ & 6.26 \\
\hline Tian FM (2016) & $\rightarrow$ & $1.83(1.04,3.83)$ & 4.68 \\
\hline Subtotal (I-squared $=0.0 \%, p=0.892)$ & $\diamond$ & $1.76(1.20,2.31)$ & 29.67 \\
\hline \multirow{2}{*}{$\begin{array}{l}\text { Heterogeneity between groups: } p=0.903 \\
\text { Overall (I-squared }=0.0 \%, p=0.977 \text { ) }\end{array}$} & & & \\
\hline & $\diamond$ & $1.79(1.48,2.09)$ & 100.00 \\
\hline-8 & & & \\
\hline
\end{tabular}

C Study ID $>80$ Duan R (2020) Chen XX (2018) Wang JS (2018) Shi HT (2017) Shi HT-1 (2017) Tian FM (2016) Wang WL (2016) Subtotal (l-squared $=0.0 \%, p=0.897)$ $<80$ Liang LL (2019) Li ZL (2019) Dong D (2019) Chen X (2018) Xie SP (2018) Nie FQ (2017) Xia BR (2017) Lv QL (2017) Subtotal (I-squared $=0.0 \%, p=0.865$ )

Heterogeneity between groups: $p=0.776$ Overall (I-squared $=0.0 \%, p=0.977$ )

b

\begin{tabular}{|c|c|c|c|}
\hline \multicolumn{2}{|l|}{$\begin{array}{l}\text { Study } \\
\text { ID }\end{array}$} & \multirow[t]{2}{*}{$\mathrm{HR}(95 \% \mathrm{Cl})$} & \multirow[t]{2}{*}{$\begin{array}{l}\% \\
\text { Weight }\end{array}$} \\
\hline indirectly & & & \\
\hline Liu JY (2020) & & $2.18(1.17,4.06)$ & 4.37 \\
\hline Duan R (2020) & 7. & $2.55(1.46,4.47)$ & 4.02 \\
\hline Liang LL (2019) & & $3.51(1.54,8.00)$ & 0.87 \\
\hline Li ZL (2019) & + & $2.33(1.24,4.38)$ & 3.70 \\
\hline Dong D (2019) & $\rightarrow$ & $1.47(0.57,3.74)$ & 3.63 \\
\hline Chen X (2018) & $\rightarrow$ & $1.39(0.50,3.84)$ & 3.27 \\
\hline Wang JS (2018) & & $2.50(1.19,5.26)$ & 2.20 \\
\hline Xie SP (2018) & + & $2.78(1.29,5.99)$ & 1.65 \\
\hline Nie FQ (2017) & + & $2.54(1.02,6.32)$ & 1.30 \\
\hline Xia BR (2017) & $\rightarrow$ & $1.50(0.79,2.83)$ & 8.76 \\
\hline Wang WL (2016) & & $1.98(1.02,3.84)$ & 4.58 \\
\hline Subtotal $(I-$ squared $=0.0 \%, p=0.935)$ & $<$ & $2.01(1.52,2.49)$ & 38.35 \\
\hline \multicolumn{4}{|l|}{ directly } \\
\hline Chen XX (2018) & $\leftarrow$ & $1.47(1.12,2.57)$ & 17.29 \\
\hline Shi HT (2017) & $\rightarrow$ & $1.59(1.07,2.36)$ & 21.91 \\
\hline Shi HT-1 (2017) & $\rightarrow$ & $1.81(1.13,2.91)$ & 11.51 \\
\hline Lv QL (2017) & $\rightarrow$ & $1.92(1.06,3.47)$ & 6.26 \\
\hline Tian FM (2016) & $\rightarrow$ & $1.83(1.04,3.83)$ & 4.68 \\
\hline Subtotal $(1-$ squared $=0.0 \%, p=0.959)$ & $\diamond$ & $1.65(1.27,2.03)$ & 61.65 \\
\hline \multicolumn{4}{|l|}{ Heterogeneity between groups: $p=0.261$} \\
\hline Overall (I-squared $=0.0 \%, p=0.977)$ & $\diamond$ & $1.79(1.48,2.09)$ & 100.00 \\
\hline
\end{tabular}

d

\begin{tabular}{|c|c|c|c|}
\hline \multicolumn{2}{|l|}{$\begin{array}{l}\text { Study } \\
\text { ID }\end{array}$} & \multirow[t]{2}{*}{$\mathrm{HR}(95 \% \mathrm{Cl})$} & \multirow[t]{2}{*}{$\begin{array}{l}\% \\
\text { Weight }\end{array}$} \\
\hline$>60$ & & & \\
\hline Liu JY (2020) & $\rightarrow$ & $2.18(1.17,4.06)$ & 4.37 \\
\hline Chen XX (2018) & $\leftarrow$ & $1.47(1.12,2.57)$ & 17.29 \\
\hline Chen X (2018) & $\rightarrow$ & $1.39(0.50,3.84)$ & 3.27 \\
\hline Shi HT (2017) & $\rightarrow$ & $1.59(1.07,2.36)$ & 21.91 \\
\hline Shi HT-1 (2017) & $\rightarrow$ & $1.81(1.13,2.91)$ & 11.51 \\
\hline Xia BR (2017) & $\rightarrow-$ & $1.50(0.79,2.83)$ & 8.76 \\
\hline Tian FM (2016) & & $1.83(1.04,3.83)$ & 4.68 \\
\hline Wang WL (2016) & $\rightarrow$ & $1.98(1.02,3.84)$ & 4.58 \\
\hline Subtotal $(I-$ squared $=0.0 \%, p=0.987$ ) & $\diamond$ & $1.65(1.30,2.00)$ & 76.37 \\
\hline \multicolumn{4}{|l|}{$<=60$} \\
\hline Duan R (2020) & $\rightarrow$ & $2.55(1.46,4.47)$ & 4.02 \\
\hline Liang LL (2019) & & $3.51(1.54,8.00)$ & 0.87 \\
\hline Li ZL (2019) & & $2.33(1.24,4.38)$ & 3.70 \\
\hline Dong D (2019) & $\rightarrow-$ & $1.47(0.57,3.74)$ & 3.63 \\
\hline Wang JS (2018) & & $2.50(1.19,5.26)$ & 2.20 \\
\hline Xie SP (2018) & + & $2.78(1.29,5.99)$ & 1.65 \\
\hline Nie FQ (2017) & & $2.54(1.02,6.32)$ & 1.30 \\
\hline Lv QL (2017) & $\rightarrow$ & $1.92(1.06,3.47)$ & 6.26 \\
\hline Subtotal $(1-$ squared $=0.0 \%, p=0.944)$ & $\infty$ & $2.23(1.61,2.85)$ & 23.63 \\
\hline \multirow{2}{*}{$\begin{array}{l}\text { Heterogeneity between groups: } p=0.110 \\
\text { Overall (I-squared }=0.0 \%, p=0.977 \text { ) }\end{array}$} & & & \\
\hline & $\diamond$ & $1.79(1.48,2.09)$ & 100.00 \\
\hline-8 & & & \\
\hline
\end{tabular}

\section{Figure 3}

Forest plot of association between ZFAS1 expression and overall survival analyzed by subgroup analysis. a Subgroup analysis by tumor type b Subgroup analysis by HR extraction methods; indirectly, HR extracted from survival curve; directly, HR extracted from paper. c subgroup analysis by sample size. d Subgroup analysis by follow-up months 
a

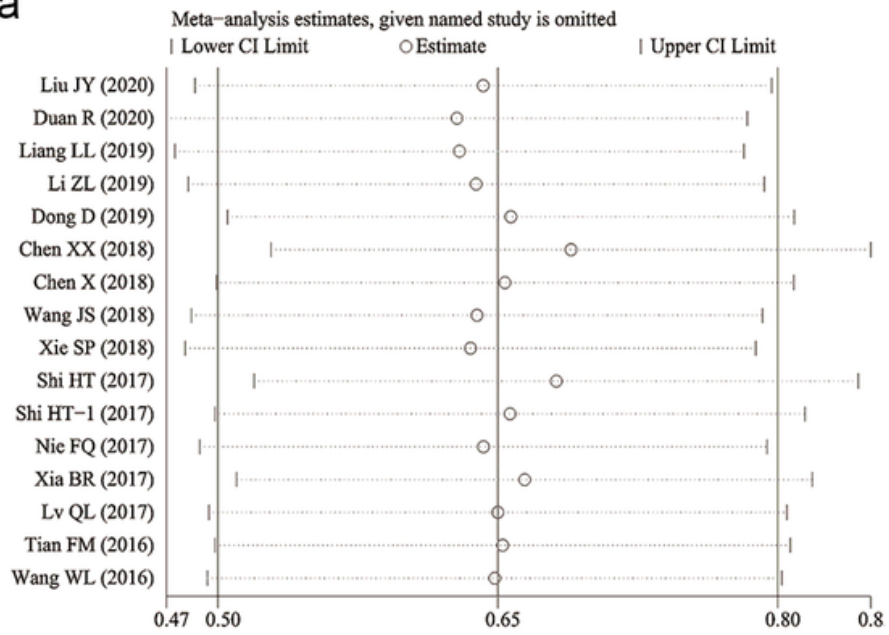

b

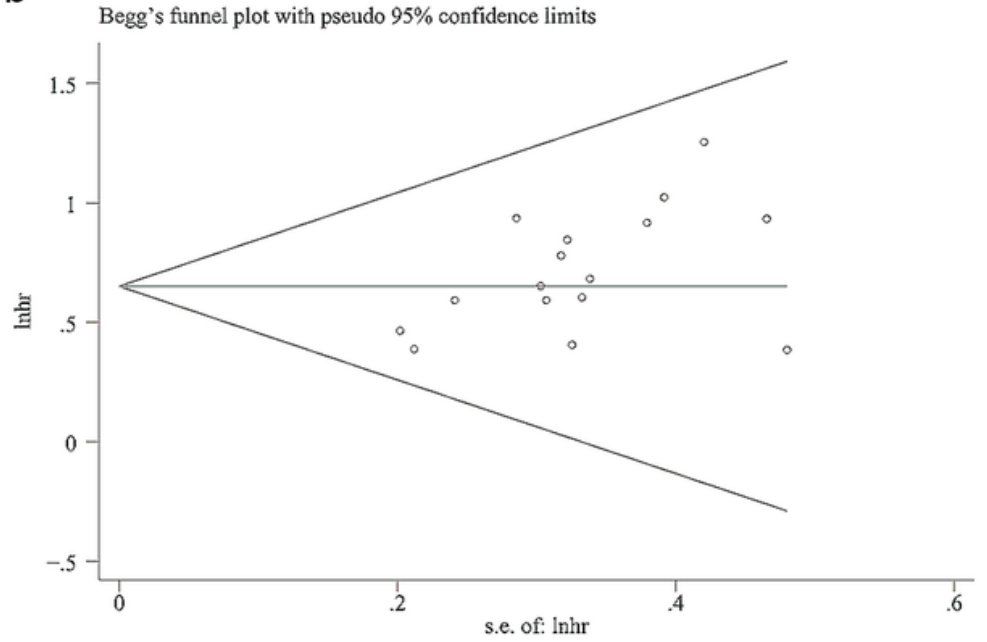

\section{Figure 4}

Analysis of stability and heterogeneity of included studies about overall survival. a Sensitivity analysis. b Begg's test.

a Study ID Liu JY (2020) Duan R (2020) Liang LL (2019) Li ZR (2019)

Cui XC (2019) Li ZL (2019) Tong HC (2019) Cui XL (2019) Dong D (2019) Chen XX (2018) Yang HF (2018) Xie SP (2018) Nie FQ (2017) Fang CY (2017) Xia BR (2017) Tian FM (2016) Wang WL (2016) Li T (2015) Overall (I-squared $=70.1 \%, p=0.000)$ NOTE: Weights are from random effects analysis .0183

C Study ID Liu JY (2020) Duan R (2020) Liang LL (2019) Li ZR (2019) Li ZL (2019) Tong HC (2019) Dong D (2019) Chen X (2018) Yang HF (2018) Xie SP (2018) Nie FQ (2017) Fang CY (2017) Xia BR (2017) Tian FM (2016) Wang WL (2016)

Overall $($ I-squared $=65.5 \%, p=0.000)$ NOTE: Weights are from random effects analysis .00145 b Study $\%$ Liu JY (2020) Duan R (2020) Li ZR (2019) Cui XC (2019) Tong HC (2019) Dong D (2019) Chen XX (2018) Chen X (2018) Yang HF (2018) Xie SP (2018) Nie FQ (2017) Fang CY (2017) Xia BR (2017) Tian FM (2016) Wang WL (2016) Li T (2015) Overall (I-squared $=65.3 \%, p=0.000$ )

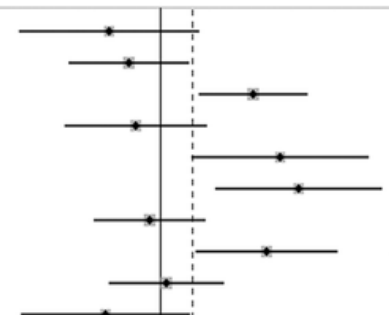
$5.36(2.29,12.57) \quad 6.24$ $3.74(1.11,12.67) \quad 4.90$ $10.45(2.92,37.39) 4.72$ $3.24(1.17,9.00) \quad 5.61$ $4.13(1.39,12.27) \quad 5.36$ $2.90(1.56,5.38) \quad 7.12$ $0.76(0.35,1.68) \quad 6.49$ $2.99(1.97,4.54) \quad 100.00$ NOTE: Weights are from random effects analysis .0506

OR $(95 \% \mathrm{Cl}) \quad$ Weight

$0.50(0.15,1.68) \quad 4.90$ $0.65(0.29,1.47) \quad 6.82$ $3.48(1.67,7.24) \quad 7.25$ $0.72(0.27,1.87) \quad 6.06$ $5.00(1.51,16.51) 4.99$ $6.42(2.08,19.76) 5.29$ $0.86(0.41,1.83) \quad 7.14$ $4.17(1.60,10.86) 6.07$ $1.08(0.50,2.35) \quad 7.01$ $0.48(0.15,1.49) \quad 5.22$ $4.04(1.30,12.58) 5.23$ $1.32(0.51,3.40) \quad 6.13$ $3.82(1.15,12.71) 4.96$ $0.96(0.53,1.77) \quad 7.95$ $1.48(0.78,2.80) \quad 7.76$ $1.28(0.61,2.69) \quad 7.21$ $1.54(1.05,2.24) \quad 100.00$

d Study $\quad \%$ Liu JY (2020) Duan R (2020) Li ZL (2019) Chen XX (2018) Yang HF (2018) Xie SP (2018) Shi HT (2017) Shi HT-1 (2017) Nie FQ (2017) Fang CY (2017) Xia BR (2017) Lv QL (2017) Tian FM (2016) Wang WL (2016) Overall (I-squared $=56.8 \%, p=0.005$ ) NOTE: Weights are from random effects analysis

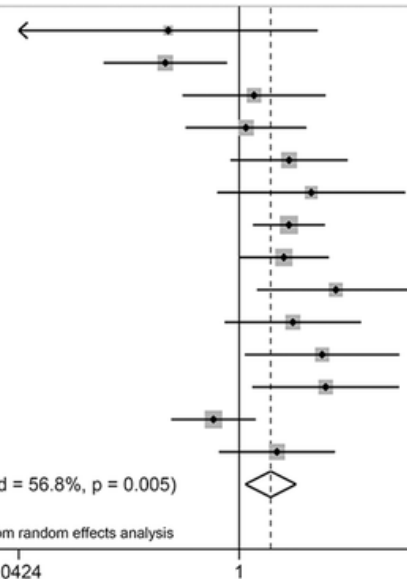

OR $(95 \% \mathrm{Cl}) \quad$ Weight

$0.36(0.04,3.09) \quad 2.38$ $0.35(0.14,0.84) \quad 7.55$ $1.24(0.44,3.46) \quad 6.54$ $1.10(0.46,2.62) \quad 7.69$ $2.05(0.88,4.75) \quad 7.89$ $2.81(0.73,10.84) \quad 4.75$ $2.04(1.22,3.42) \quad 10.69$ $1.90(0.99,3.62) \quad 9.53$ $4.00(1.29,12.40) \quad 5.88$ $2.16(0.81,5.75) \quad 6.86$ $3.29(1.08,9.95) \quad 6.02$ $3.46(1.21,9.92) \quad 6.37$ $0.69(0.38,1.27) \quad 9.89$ $1.72(0.75,3.95) \quad 7.96$ $1.57(1.09,2.26) \quad 100.00$ 
Forest plot of relation between ZFAS1 expression and clinicopathologic features. a Relation between ZFAS1 expression and HTS. b Relation between ZFAS1 expression and LTS. c Relation between ZFAS1 expression and LNM. d Relation between ZFAS1 expression and PHG.
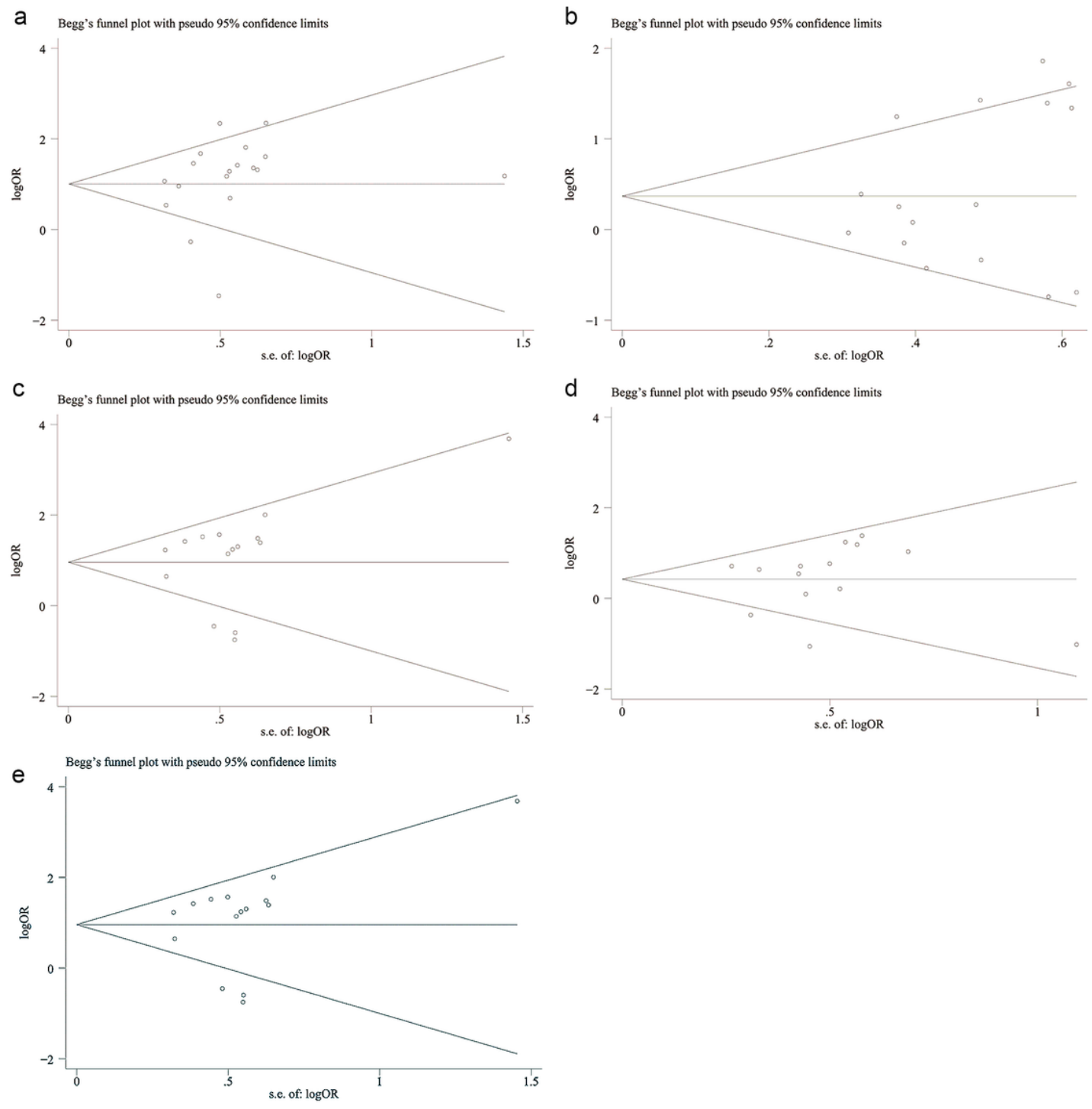

\section{Figure 6}

Begg's test of included studies about clinicopathologic features. a Begg's test of HTS. b Begg's test of LTS. c Begg's test of LNM. d Begg's test of PHG. e Begg's test of DM 


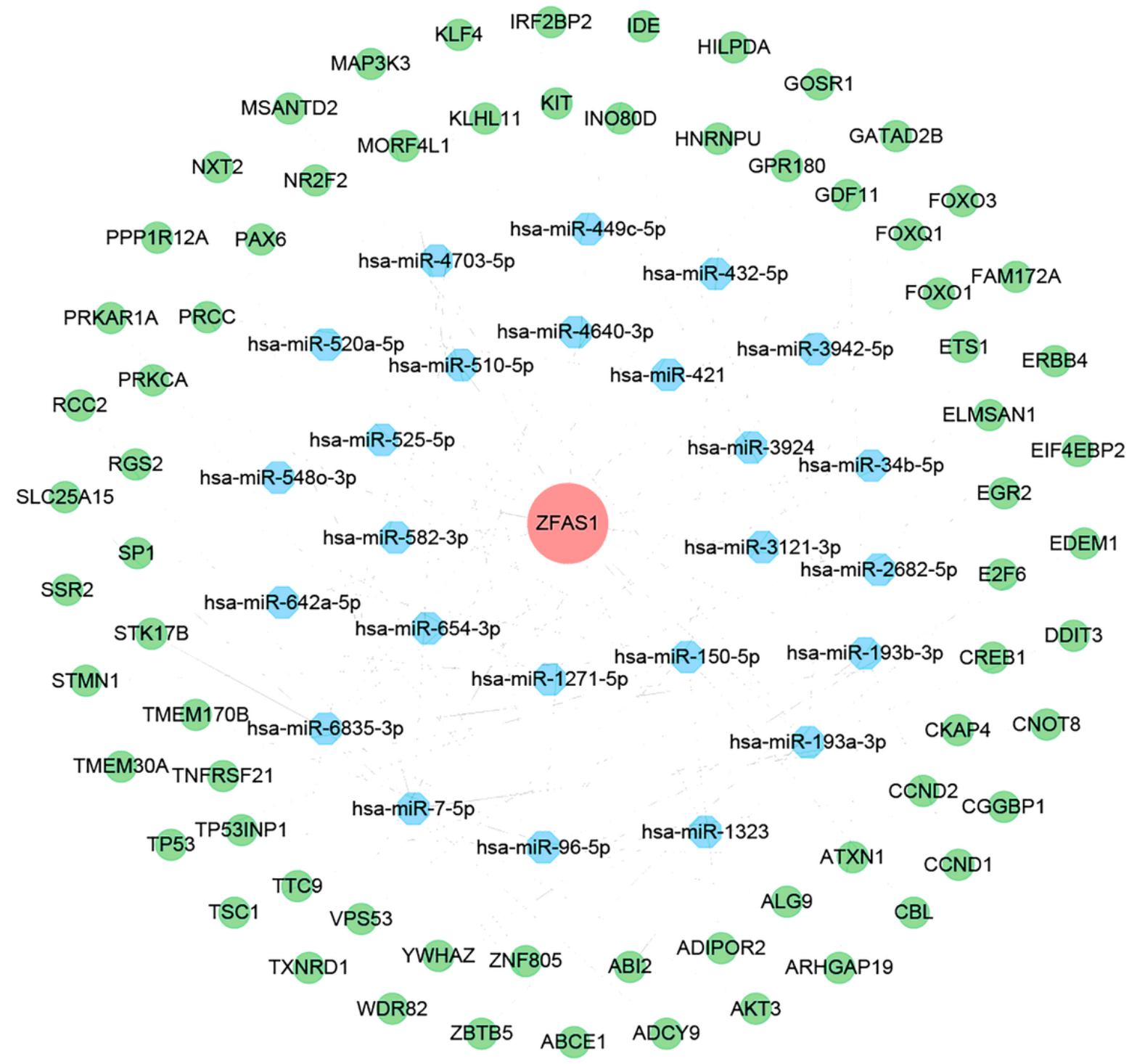

Figure 7

CeRNA network of ZFAS1 participated in.

a

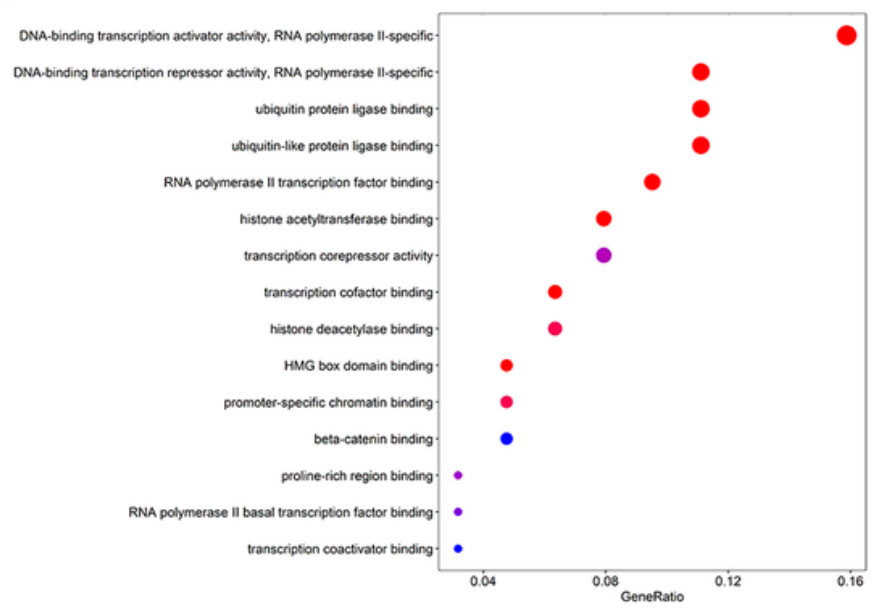

b

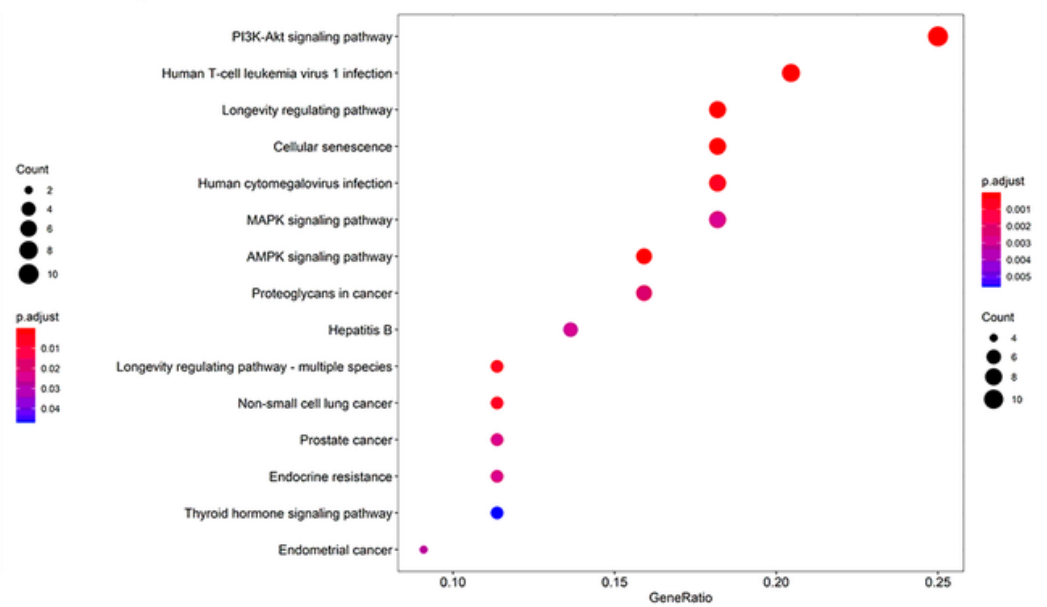

Figure 8 
GO and KEGG analysis of targeted mRNAs. a GO analysis. b KEGG analysis.

\section{Supplementary Files}

This is a list of supplementary files associated with this preprint. Click to download.

- Additionalfile1.tif

- PRISMA2009checklist.doc 